\title{
ATP7A wt Allele
}

National Cancer Institute

\section{Source}

National Cancer Institute. ATP7A wt Allele. NCI Thesaurus. Code C74974.

Human ATP7A wild-type allele is located within Xq13.2-q13.3 and is approximately $139 \mathrm{~kb}$ in length. This allele, which encodes copper-transporting ATPase 1 protein, plays a role in the localization of copper ions. Mutations in the gene are associated with both Menkes disease and occipital horn syndrome. 